$\mathrm{Nr} 8$

WARSZAWA-KRAKÓW 2006

ELIZA WAJDA

Akademia Pedagogiczna, Kraków

\title{
Rozwój i struktura przestrzenna działalności firmy Nokia w latach 1997-2003
}

W dobie nasilających się przemian globalizacji zachodzących na rynku światowym coraz większą rolę odgrywają korporacje transnarodowe, a wśród nich firmy związane z branżą telekomunikacyjną. Zajmujące się technologią informacyjną firmy ujednolicają świat i przyspieszają jego rozwój gospodarczy i społeczny (Zioło 2001). Wśród światowych firm telekomunikacyjnych najważniejsza rolę odgrywają korporacje: Nokia, Siemens, Alcatel, Motorola i Ericsson, które łącznie w roku 2003 osiągnęły wartość rynkową 176 mld USD.

Niniejsze rozważania poświęcono procesowi kształtowania ponadnarodowej firmie Nokia, światowemu liderowi w dziedzinie komunikacji bezprzewodowej. Dzięki swemu doświadczeniu, innowacyjności oraz łatwym w obsłudze rozwiązaniom, firma zajmuje czołową pozycję wśród producentów telefonów komórkowych, a także jest jednym z głównych dostawców sieci komórkowych, szerokopasmowych sieci stacjonarnych oraz sieci IP. Łącząc mobilność z Internetem, Nokia otwiera nowe możliwości przed firmami oraz ułatwia powszednie życie ludzi. Jest jedną z najbardziej znanych na świecie firm, a jej akcje są notowane na sześciu światowych giełdach (www.nokia.com). W pracy wykorzystano metodę indukcyjną która polega na porównywaniu i systematyzowaniu faktów (Berezowski 1980), do interpretacji danych zastosowano metody statystyczne, natomiast za pomocą metod kartograficznych przedstawiono zagadnienia przestrzenne.

Intensywny rozwój korporacji Nokia rozpoczyna się od roku 1996, kiedy firma zaczęła odgrywać ważną rolę $\mathrm{w}$ przemyśle telekomunikacyjnym. Wskazuje na to jej zmieniająca się pozycja w rankingu korporacji światowych The Global 1000, publikowanym przez magazyn „Business Week”.

Analizując najważniejsze światowe firmy telekomunikacyjne można zauważyć zmienianie ich wartości rynkowej. W roku 1997 największą wartość rynkową 39 mld USD posiadała amerykańska firma Motorola, zajmująca 60 miejsce na liście największych światowych korporacji. W pierwszej 100 najwartościowszych firm znalazła się także szwedzka firma Ericsson, której wartość rynkowa wynosiła 34 mld USD, co dawało jej 71 miejsce, oraz niemiecka firma Siemens, zajmująca 77 miejsce z wartością rynkową 32 mld USD (tab. 1). W roku tym Nokia zajmowała miejsce 166, osiagając wartość rynkową 19,6 mld USD, w latach następnych zajmowała już coraz wyższą lokatę w rankingu. Wartość rynkowa w latach 1996-2003 sytuowała firmę na miejscu 224 w 1996, natomiast w 2003 r. na miejscu 27 (tab. 2). 


\begin{tabular}{|c|c|c|c|c|c|c|c|}
\hline \multirow{7}{*}{ 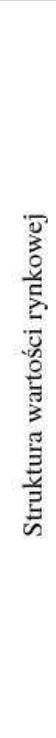 } & శ్రి & $\begin{array}{c}\infty \\
\substack{0 \\
o f} \\
o\end{array}$ & $\begin{array}{l}\stackrel{2}{0} \\
\text { ते }\end{array}$ & $\stackrel{\text { I }}{=}$ & ईे & $\begin{array}{l}\infty \\
\text { h్ }\end{array}$ & $\begin{array}{l}8 \\
8 \\
8\end{array}$ \\
\hline & ઠิે & के & $\begin{array}{l}\text { Cे } \\
\infty \\
\text { id }\end{array}$ & $\begin{array}{l}\hat{a} \\
\stackrel{\infty}{a}\end{array}$ & $\stackrel{q}{\alpha}$ & ?r & $\begin{array}{l}8 \\
8 \\
8\end{array}$ \\
\hline & $\overline{\mathrm{d}}$ & $\begin{array}{c}\infty \\
\text { m. } \\
q\end{array}$ & $\begin{array}{l}\text { fo } \\
\text { \&े }\end{array}$ & $\begin{array}{l}\text { i̊ } \\
\stackrel{1}{\varrho}\end{array}$ & $\begin{array}{l}\infty \\
\infty \\
\infty \\
\\
\end{array}$ & $\stackrel{\infty}{\infty}$ & $\begin{array}{l}8 \\
\stackrel{8}{0}\end{array}$ \\
\hline & \&్రి & $\cong$ & $\begin{array}{l}\overline{0} \\
\dot{ \pm}\end{array}$ & $\begin{array}{l}\infty \\
\infty \\
0 \\
0\end{array}$ & $\begin{array}{l}\hat{n} \\
\text { ñ }\end{array}$ & $\begin{array}{l}\infty \\
\stackrel{+}{0} \\
\stackrel{0}{0}\end{array}$ & 8 \\
\hline & $\stackrel{\text { }}{ }$ & $\begin{array}{l}\text { in } \\
\text { in } \\
\text { f. }\end{array}$ & $\begin{array}{l}\underset{F}{f} \\
\text { 正 }\end{array}$ & $\begin{array}{l}\stackrel{2}{2} \\
\stackrel{2}{0}\end{array}$ & $\begin{array}{l}\hat{\infty} \\
\infty \\
\text { ते }\end{array}$ & 寺 & $\begin{array}{l}8 \\
8\end{array}$ \\
\hline & $\stackrel{\infty}{\stackrel{2}{\sigma}}$ & $\begin{array}{l}\stackrel{\infty}{\infty} \\
\stackrel{0}{\Omega}\end{array}$ & $\begin{array}{l}\tilde{0} \\
\infty \\
\infty\end{array}$ & $\begin{array}{l} \pm \\
\text { in }\end{array}$ & के & in & 8 \\
\hline & $\hat{\mathrm{a}}$ & $\stackrel{\infty}{\stackrel{0}{\varrho}}$ & $\begin{array}{l}\text { t. } \\
\text { di }\end{array}$ & $\begin{array}{l}\mathbb{R} \\
\tilde{N}\end{array}$ & \& & ñ & 8 \\
\hline \multirow{7}{*}{ 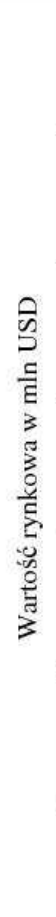 } & ઠ్రి & $\begin{array}{l}\circ \\
\& \\
\infty \\
\infty\end{array}$ & 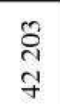 & $\begin{array}{l}\text { O } \\
\stackrel{2}{a}\end{array}$ & 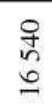 & $\begin{array}{l}\infty \\
\stackrel{\infty}{n} \\
=\end{array}$ & $\frac{9}{6}$ \\
\hline & ठั. & $\frac{\infty}{\frac{1}{6}}$ & $\begin{array}{l}\vec{E} \\
\stackrel{+}{W}\end{array}$ & 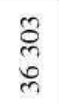 & $\begin{array}{l}\text { ț } \\
0 \\
\stackrel{\infty}{0}\end{array}$ & $\begin{array}{l}\tilde{\sigma} \\
\tilde{\Xi} \\
\pm\end{array}$ & 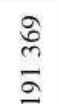 \\
\hline & ఫ్ڤે & $\begin{array}{l}\stackrel{m}{2} \\
\stackrel{0}{n}\end{array}$ & $\begin{array}{l}\overrightarrow{2} \\
\hat{\beta}\end{array}$ & 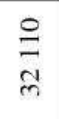 & $\begin{array}{l}n \\
2 \\
\text { on } \\
\text { a }\end{array}$ & $\begin{array}{l}\hat{F} \\
0 \\
0\end{array}$ & $\begin{array}{l}\frac{y}{w} \\
\text { d } \\
\frac{1}{m}\end{array}$ \\
\hline & ષ્તે & $\frac{\infty}{\stackrel{\infty}{c}}$ & 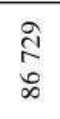 & \begin{tabular}{l}
$\stackrel{0}{+}$ \\
\multirow{6}{*}{}
\end{tabular} & 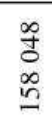 & $\begin{array}{l}\frac{m}{2} \\
\dot{b}\end{array}$ & $\frac{\bar{a}}{\frac{a}{b}}$ \\
\hline & 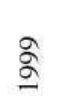 & $\begin{array}{l}\text { ते } \\
\text { ¿ }\end{array}$ & $\begin{array}{l}\hat{⿵} \\
\infty \\
\infty \\
\infty\end{array}$ & $\begin{array}{l}\stackrel{q}{q} \\
\infty \\
q\end{array}$ & $\begin{array}{l}\infty \\
\text { o } \\
\text { N } \\
\text { nn }\end{array}$ & $\begin{array}{l}\overline{3} \\
\infty \\
\vec{\lambda}\end{array}$ & $\begin{array}{l}\text { ते } \\
\text { ते } \\
\text { ते }\end{array}$ \\
\hline & $\stackrel{\infty}{\stackrel{2}{\sigma}}$ & $\begin{array}{l}\vec{\infty} \\
\text { oे } \\
\text { ले }\end{array}$ & $\begin{array}{l}\text { ơ } \\
\text { के }\end{array}$ & $\frac{5}{m}$ & $\begin{array}{l}\text { तु } \\
\text { in }\end{array}$ & $\begin{array}{l}\stackrel{b}{a} \\
\stackrel{+}{0}\end{array}$ & $\begin{array}{l}\stackrel{0}{\circ} \\
\infty \\
\infty\end{array}$ \\
\hline & $\hat{a}$ & \&: & $\underset{I}{\overrightarrow{0}}$ & $\frac{\infty}{\not}$ & $\underset{\substack{a \\
\infty}}{\substack{0 \\
0}}$ & 象 & $\stackrel{\circ}{2}$ \\
\hline & & $\begin{array}{l}\frac{g}{8} \\
\\
Z\end{array}$ & 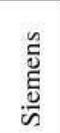 & $\begin{array}{l}\frac{\pi}{0} \\
\frac{0}{0} \\
\frac{0}{0}\end{array}$ & $\begin{array}{l}\tilde{5} \\
\tilde{y} \\
\tilde{n}\end{array}$ & 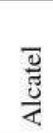 & $\begin{array}{l}E \\
\text { हूँ } \\
\check{\simeq}\end{array}$ \\
\hline
\end{tabular}


Tabela 2. Zmiana pozycji firm telekomunikacyjnych na liście The Global 1000 w latach 1996-2003

\begin{tabular}{|l|r|r|r|r|r|r|r|c|}
\hline Wyszczególnienie & \multicolumn{1}{|c|}{1996} & \multicolumn{1}{|c|}{1997} & 1998 & 1999 & 2000 & 2001 & 2002 & 2003 \\
\hline Nokia & 224 & 166 & 87 & 38 & 9 & 20 & 48 & 27 \\
\hline Simens & 60 & 77 & 97 & 109 & 53 & 61 & 61 & 78 \\
\hline Alcatel & 214 & 199 & 101 & 191 & 75 & 161 & 289 & 338 \\
\hline Motorola & 41 & 60 & 118 & 85 & 70 & 151 & 108 & 185 \\
\hline Ericsson & 112 & 71 & 60 & 77 & 22 & 87 & 230 & 228 \\
\hline
\end{tabular}

Źródło: www.bussinesweek.com

W latach 1998-2000 Nokia wyprzedziła wszystkie firmy telekomunikacyjne i znalazła się w pierwszej dziesiątce najpotężniejszych korporacji światowych, zajmując miejsce 9 z wartością rynkową 242 mld USD. W roku 2000 na bardzo mocnej pozycji znaleźli się wszyscy dostawcy usług telekomunikacyjnych, firmy produkujące telefony komórkowe i inne urządzenia do sieci. W ciagu roku dynamicznie wzrosła wartość rynkowa europejskich firm telekomunikacyjnych. Wartość rynkowa Nokii i wzrosła prawie 3-krotnie z 87 mld USD do 242 mld USD. Do sytuacji tej przyczynił się fakt, iż w Europie rozpoczęła się kolejna faza rewolucji cyfrowej. W roku 2001 nastąpiło obniżenie wartości rynkowej firmy do 136 mld USD, co przyczyniło się do zajęcia 20 miejsca w rankingu, a w roku 2002 nastąpił spadek do 48 miejsca z wartością rynkową 67,7 mld USD. Należy jednak zwrócić uwagę, że w tym okresie wszystkie wcześniej wymienione firmy telekomunikacyjne straciły na wartości rynkowej, co w rezultacie odbiło się na spadku ich pozycji na liście The Global 1000. W roku 2001 przyczyną spadku mógł być fakt, iż europejscy operatorzy telefonii komórkowej zobowiązali się zapłacić opłaty licencyjne w wysokości 116 mld USD na rzecz telefonii komórkowej nowej generacji. Okazało się jednak, że firmy te nie są w stanie pokryć zobowiązań. Operatorzy sieci komórkowych dbali o krótkoterminowe przepływy pieniężne i redukcję długów, ograniczając jednocześnie inwestycje kapitałowe. Problemy operatorów przyczyniły się do pogorszenia sytuacji dostawców i producentów telefonii komórkowej i obniżenia ich wartości rynkowej.

Warto tu zaznaczyć, że w ciągu ośmiu lat Nokia wspięła się z miejsca 224 w 1996 r. do 27 w roku 2003, czyli o 197 miejsc. W latach 1997-2003 rozwijała się bardzo dynamicznie, do roku 2000 wartość rynkowa firmy wzrosła ponad 12-krotnie, osiagając w 2000 r. 242,19 mld USD (tab. 3).

Tabela 3. Dynamika wartości rynkowej firm telekomunikacyjnych w latach 1997-2003

\begin{tabular}{|l|c|r|r|r|r|r|r|}
\hline Wyszczególnienie & 1997 & \multicolumn{1}{|c|}{1998} & 1999 & \multicolumn{1}{c|}{2000} & \multicolumn{1}{c}{2001} & \multicolumn{1}{c|}{2002} & \multicolumn{1}{c|}{2003} \\
\hline Nokia & 100,00 & 201,43 & 444,91 & 1235,64 & 694,56 & 345,50 & 439,21 \\
\hline Siemens & 100,00 & 116,69 & 122,41 & 273,07 & 200,66 & 172,45 & 132,88 \\
\hline Motorola & 100,00 & 80,36 & 126,46 & 170,60 & 81,46 & 92,10 & 50,05 \\
\hline Ericsson & 100,00 & 164,33 & 155,30 & 466,92 & 146,52 & 53,34 & 48,86 \\
\hline Alcatel & 100,00 & 198,75 & 135,65 & 369,50 & 175,17 & 82,67 & 65,96 \\
\hline Razem & 100,00 & 139,78 & 177,45 & 435,40 & 219,66 & 134,58 & 123,88 \\
\hline
\end{tabular}

Źródło: własne obliczenia na podstawie danych www.nokia.com 
Biorąc pod uwagę zyski firm w 2003 r., największy zysk osiągnęła Nokia (3977 mln USD) oraz Siemens (3054 mln USD) - zob. tab. 4. Natomiast największe straty poniosła francuska firma Alcatel (-5581 mln USD).

Tabela 4. Zmiana zysku (w mln USD) firm telekomunikacyjnych w latach 1997-2003

\begin{tabular}{|l|r|c|r|r|r|r|r|}
\hline Wyszczególnienie & \multicolumn{1}{|c|}{1997} & 1998 & 1999 & 2000 & 2001 & 2002 & 2003 \\
\hline Nokia & 1227 & 1764 & 2598 & 3969 & 2218 & 3408 & 3977 \\
\hline Siemens & 1336 & 1343 & 1280 & 1730 & 2866 & 1951 & 3054 \\
\hline Motorola & 920 & 1525 & 1514 & 1346 & 1952 & -2183 & -2448 \\
\hline Ericsson & 1154 & 1180 & 347 & 1209 & 1318 & -3937 & -2485 \\
\hline Alcatel & 469 & 780 & 731 & 597 & 1122 & -4637 & -5581 \\
\hline Razem & 5106 & 6592 & 6470 & 8851 & 9476 & -5398 & -3483 \\
\hline
\end{tabular}

Źródło: www.bussinesweek.com

\section{PROCES KSZTAETOWANIA SIĘ NOKIA GROUP}

Proces kształtowania się korporacji Nokia rozpoczął się w 1865 roku, kiedy inżynier górnictwa Fredrik Idestam założył w południowo-zachodniej Finlandii zakład przetwórstwa drewna produkujący papier, będący w ówczesnych czasach nośnikiem informacji. W innym miejscu kraju w 1898 roku powstały Fińskie Zakłady Gumowe, a w roku 1912 - Fińska Fabryka Kabli, zajmująca się produkcją kabli do telegrafów oraz do nowego urządzenia, jakim był telefon. W roku 1960 w Fińskiej Fabryce Kabli uruchomiono dział elektroniczny, będący zaczątkiem torowania drogi do nowej ery telekomunikacyjnej. Udziały w tych dwóch firmach oraz w firmie Nokia stopniowo przechodziły w ręce niewielkiej grupy właścicieli. Ostatecznie w 1967 roku trzy przedsiębiorstwa: fabrykę papieru, zakłady gumowe oraz fabrykę kabli połączono w jedną firmę Nokia Corporation.

W latach 60. firma wprowadza na rynek nowość, jaką były kolorowe gumowe kalosze. Rok 1963 przynosi radiotelefon, a dwa lata później zostaje opracowany modem do transmisji danych. W latach 80. Nokia staje się czołowym producentem komputerów, monitorów i telewizorów. W tym okresie w Skandynawii zostaje uruchomiona pierwsza na świecie sieć telefonii komórkowej - NMT, a Nokia uruchamia produkcję pierwszych modelów telefonów komórkowych wypuszczając na rynek Nokia Cityman. Na początku lat 80 . firma umacnia swoją pozycję na rynku telekomunikacyjnym i elektroniki użytkowej, włączając do swej korporacji firmy Mobira, Salora, Televa i szwedzką firmę Luxor. W 1987 roku przejęła od niemieckiej firmy Standard Elektrik Lorenz oddział produkujący sprzęt elektroniczny oraz część oddziału produkcji podzespołów, a także francuską firmę z branży elektroniki użytkowej Oceanic. W tym samym roku kupiła szwajcarską fabrykę urządzeń do produkcji kabli Maillefer.

Pod koniec lat 80. Nokia stała się największą firmą informatyczną w całej Skandynawii na skutek przejęcia od firmy Ericsson działu systemów przetwarzania danych. W 1989 roku znacznie zwiększyła swój udział w europejskim rynku produkcji kabli, przejmując holenderską firmę NKF (www.nokia.pl). W roku 1987 wyprodukowano pierwszy przenośny tele- 
fon Nokia Cityman. Od tego czasu rozmiary i waga telefonów komórkowych szybko maleje. W roku 1991 wprowadza do swoich urządzeń standard GSM. Wiek XXI przynosi szybki rozwój nowych technologii, wprowadzane zostają m.in. MMS-y, czyli wiadomości multimedialne umożliwiające przesyłanie plików dźwiękowych, zdjęć i krótkich filmów. W przyszłości korporacja planuje wprowadzenie inteligentnych sal konferencyjnych.

W procesie kształtowania się korporacji doskonaliła się jej struktura wewnętrzna. W roku 1990 w strukturach firmy działało 7 sektorów: Nokia Telecommunications, Nokia Mobile Phones, Nokia Consumer i Industrial Electronics, Nokia Data Cables \& Machinery oraz Basic Industries. W roku 1994 struktura wewnętrzna firmy uległa modyfikacji i pozostały w niej 3 najważniejsze sektory: Nokia Telecommunications Nokia Mobile Phones i Inne. Obecnie firma składa się z 5 samodzielnych sektorów: Nokia Mobile Phones, Nokia Networks, Nokia Ventures Organization, Resarch and Development oraz Inne. Warto zwrócić uwagę, iż jedyny sektor, który utrzymał się w strukturach firmy, jest sektor Nokia Mobile Phone. Przyczyną tego jest ciągły rozwój przemysłu telefonii komórkowej. Poszczególne sektory spełniają w strukturze korporacji odmienne funkcje, a tym samym wpływając na podnoszenie jej konkurencyjności.

\section{Nokia Ventures Organization}

- tworzy nowe pomysły na działalność,

- rozwija nowe koncepcje, które są później przejmowane i wykorzystywane przez inne działy,

- stworzono sieć współpracy, która jednoczy przedsiębiorców z wewnątrz i spoza firmy: Insight \& Foresight (badająca przyszłość w czterech różnych dziedzinach: zjawisk społecznoekonomicznych, potrzeb użytkowników, systemu przedsiębiorstw i techniki) oraz New Growth Businesses, która opracowuje nowe, strategiczne koncepcje działalności rynkowej i nadaje im praktyczny wymiar,

- obejmuje też dwa dojrzałe przedsięwzięcia, które osiągnęły rozmiary sporych przedsiębiorstw: Nokia Internet Communications oraz Nokia Home Communications.

Nokia Home Communications ma siedzibę w Mountain View w Kalifornii. Jej zadaniem jest umożliwienie firmom wymiany informacji i prowadzenie działalności w sposób bezpieczny, szybki i niezawodny. Oferuje rozwiązania z dziedziny bezpieczeństwa sieci, wirtualnych sieci prywatnych i ruchu internetowego. Tworzy cyfrowe platformy do zastosowań domowych oraz rozwiązania komunikacyjne oparte na technologii IP z przeznaczeniem dla urządzeń codziennego użytku.

\section{Nokia Venture Partners}

- inwestuje w początkujące firmy z branży telefonii komórkowej i rozwiązań IP,

- otwarta jest na rynki, technologie i modele działalności wykraczające poza aktualne strategie jednostek organizacyjnych.

\section{Centrum Rozwoju Badawczego}

- dysponuje 10 dużymi ośrodkami w 7 krajach,

- poszukuje rozwiązań na przyszłość, tworząc jednocześnie rozwiązania techniczne przydatne już dzisiaj. Dział ten tworzy sieć zwaną strategiczną macierzą, obejmującą sześć głównych obszarów o strategicznym znaczeniu dla firmy, z których każdy ma właściciela i jasno określony cel badawczo-rozwojowy. Umożliwia to wykorzystanie wiedzy i umiejętności wszystkich posiadanych przez Nokię laboratoriów.

Nokia Mobile Phones

- sektor ten jest największym na świecie producentem telefonów komórkowych, 
- produkuje telefony komórkowe posiadające funkcje od transmisji głosu po transmisję danych multimedialnych i zdjęć oraz aplikacje rozrywkowe.

\section{Nokia Networks}

- projektuje rozwiązania z dziedziny sieci i łączności, które umożliwią operatorom lepszą obsługę klientów,

- strategia firmy koncentruje się na trzech podstawowych dziedzinach: wzroście, wydajności i rentowności.

\section{LOKALIZACJA PRZESTRZENNA}

Rozwijająca się korporacja w oparciu o sieciowe reguły zarządzania poszukiwała nowych miejsc dla lokalizacji swoich przedstawicielstw i oddziałów produkcyjnych. Generalnie nawiązywano do chłonności istniejących i potencjalnych rynków zbytu. Obecnie Nokia posiada swoje oddziały na całym świecie. Można jednak wyróżnić 3 centra: Stany Zjednoczone (13 oddziałów), Brazylia (7) oraz Azja Południowo-Wschodnia (tab. 5, ryc. 1). W Europie najwięcej oddziałów zlokalizowanych jest w Wielkiej Brytanii (7), w Niemczech (4), Włoszech (4) i Finlandii (4). Należy tu zaznaczyć, że sektory zlokalizowane są na obszarach lepiej rozwiniętych (ryc. 2, 3, 4).

Tabela 5. Lokalizacja oddziałów Nokia na świecie w 2003 r.

\begin{tabular}{|l|c|c|c|c|c|}
\hline \multicolumn{1}{|c|}{ Państwo } & $\begin{array}{c}\text { Liczba } \\
\text { oddziałów }\end{array}$ & $\begin{array}{c}\text { Nokia } \\
\text { Mobile Phones }\end{array}$ & $\begin{array}{c}\text { Nokia } \\
\text { Networks }\end{array}$ & $\begin{array}{c}\text { Nokia Ventures } \\
\text { Organization }\end{array}$ & $\begin{array}{c}\text { Rozwój } \\
\text { i badania }\end{array}$ \\
\hline Stany Zjednoczone & 13 & $\mathrm{X}$ & $\mathrm{X}$ & $\mathrm{X}$ & $\mathrm{X}$ \\
\hline Brazylia & 7 & $\mathrm{X}$ & $\mathrm{X}$ & & \\
\hline Wielka Brytania & 7 & $\mathrm{X}$ & $\mathrm{X}$ & $\mathrm{X}$ & $\mathrm{X}$ \\
\hline Chiny & 7 & $\mathrm{X}$ & $\mathrm{X}$ & $\mathrm{X}$ & \\
\hline Indie & 6 & $\mathrm{X}$ & $\mathrm{X}$ & & $\mathrm{X}$ \\
\hline Finlandia & 4 & $\mathrm{X}$ & & & \\
\hline Niemcy & 4 & $\mathrm{X}$ & $\mathrm{X}$ & $\mathrm{X}$ & \\
\hline Włochy & 4 & $\mathrm{X}$ & $\mathrm{X}$ & $\mathrm{X}$ & \\
\hline Szwajcaria & 4 & & $\mathrm{X}$ & & \\
\hline Kanada & 3 & $\mathrm{X}$ & & $\mathrm{X}$ & $\mathrm{X}$ \\
\hline Hiszpania & 3 & $\mathrm{X}$ & $\mathrm{X}$ & $\mathrm{X}$ & \\
\hline Japonia & 3 & $\mathrm{X}$ & $\mathrm{X}$ & $\mathrm{X}$ & $\mathrm{X}$ \\
\hline Meksyk & 2 & $\mathrm{X}$ & $\mathrm{X}$ & $\mathrm{X}$ & \\
\hline Austria & 2 & $\mathrm{X}$ & $\mathrm{X}$ & & \\
\hline Belgia & 2 & $\mathrm{X}$ & $\mathrm{X}$ & $\mathrm{X}$ & \\
\hline Węgry & 2 & $\mathrm{X}$ & $\mathrm{X}$ & & \\
\hline Norwegia & 2 & $\mathrm{X}$ & $\mathrm{X}$ & $\mathrm{X}$ & \\
\hline
\end{tabular}


Rozwój i struktura przestrzenna...

\begin{tabular}{|c|c|c|c|c|c|}
\hline Rosja & 2 & & & & \\
\hline Szwecja & 2 & $\mathrm{X}$ & $\mathrm{X}$ & $\mathrm{X}$ & \\
\hline Turcja & 2 & $\mathrm{X}$ & $\mathrm{X}$ & & \\
\hline Tajwan & 2 & $\mathrm{X}$ & $\mathrm{X}$ & $\mathrm{X}$ & \\
\hline Nowa Zelandia & 2 & $\mathrm{X}$ & $\mathrm{X}$ & & \\
\hline Korea Południowa & 2 & $\mathrm{X}$ & $\mathrm{X}$ & $\mathrm{X}$ & \\
\hline Argentyna & 1 & $\mathrm{X}$ & $\mathrm{X}$ & & \\
\hline Chile & 1 & $\mathrm{X}$ & & $\mathrm{X}$ & \\
\hline Kolumbia & 1 & & $\mathrm{X}$ & & \\
\hline Peru & 1 & $\mathrm{X}$ & $\mathrm{X}$ & & \\
\hline Wenezuela & 1 & & $X$ & & \\
\hline Bułgaria & 1 & $\mathrm{X}$ & $\mathrm{X}$ & & \\
\hline Czechy & 1 & $\mathrm{X}$ & $X$ & & \\
\hline Dania & 1 & $X$ & $X$ & $\mathrm{X}$ & \\
\hline Francja & 1 & $\mathrm{X}$ & $\mathrm{X}$ & $\mathrm{X}$ & \\
\hline Grecja & 1 & & $\mathrm{X}$ & & \\
\hline Irlandia & 1 & $X$ & $\mathrm{X}$ & & \\
\hline Łotwa & 1 & & $\mathrm{X}$ & & \\
\hline Litwa & 1 & & $X$ & & \\
\hline Holandia & 1 & $X$ & $\mathrm{X}$ & & \\
\hline Polska & 1 & $\mathrm{X}$ & $\mathrm{X}$ & $\mathrm{X}$ & \\
\hline Portugalia & 1 & $X$ & $\mathrm{X}$ & & \\
\hline Rumunia & 1 & $\mathrm{X}$ & $X$ & & \\
\hline Słowacja & 1 & & $\mathrm{X}$ & & \\
\hline Australia & 1 & $\mathrm{X}$ & $X$ & $\mathrm{X}$ & $\mathrm{X}$ \\
\hline Hongkong & 1 & $\mathrm{X}$ & $\mathrm{X}$ & $\mathrm{X}$ & \\
\hline Indonezja & 1 & $\mathrm{X}$ & $\mathrm{X}$ & & \\
\hline Malezja & 1 & $X$ & $\mathrm{X}$ & $\mathrm{X}$ & \\
\hline Filipiny & 1 & $\mathrm{X}$ & $\mathrm{X}$ & & \\
\hline Singapur & 1 & $\mathrm{X}$ & $\mathrm{X}$ & $\mathrm{X}$ & \\
\hline Tajlandia & 1 & $X$ & $\mathrm{X}$ & $\mathrm{X}$ & \\
\hline Wietnam & 1 & $X$ & & & \\
\hline Maroko & 1 & & $\mathrm{X}$ & & \\
\hline Południowa Afryka & 1 & & $\mathrm{X}$ & & \\
\hline $\begin{array}{l}\text { Zjednocz. Emiraty } \\
\text { Arabskie }\end{array}$ & 1 & $\mathrm{X}$ & $\mathrm{X}$ & & \\
\hline Suma & & 42 & 47 & 24 & 6 \\
\hline
\end{tabular}

Źródło: na podstawie www.nokia.com 


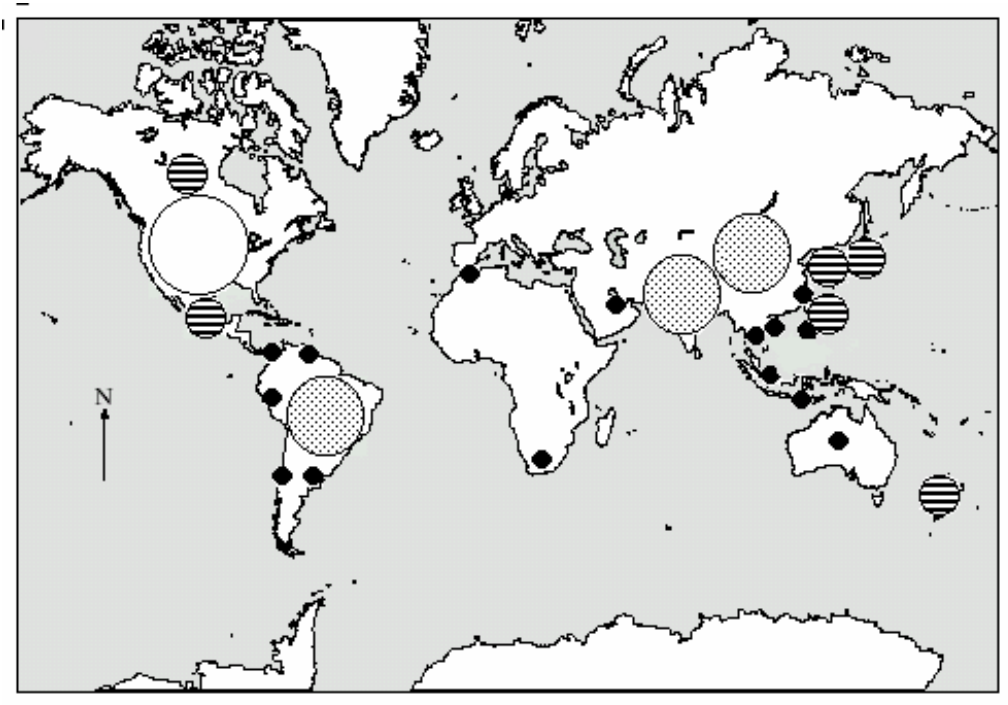

Ryc. 1. Lokalizacja oddziałów na świecie (z pominięciem Europy) w 2003 r. Legenda: 1 oddział $; 2-3 \ominus ; 4-5 \otimes ; 6-7 \bigcirc ;$ pow. $7 \bigcirc$

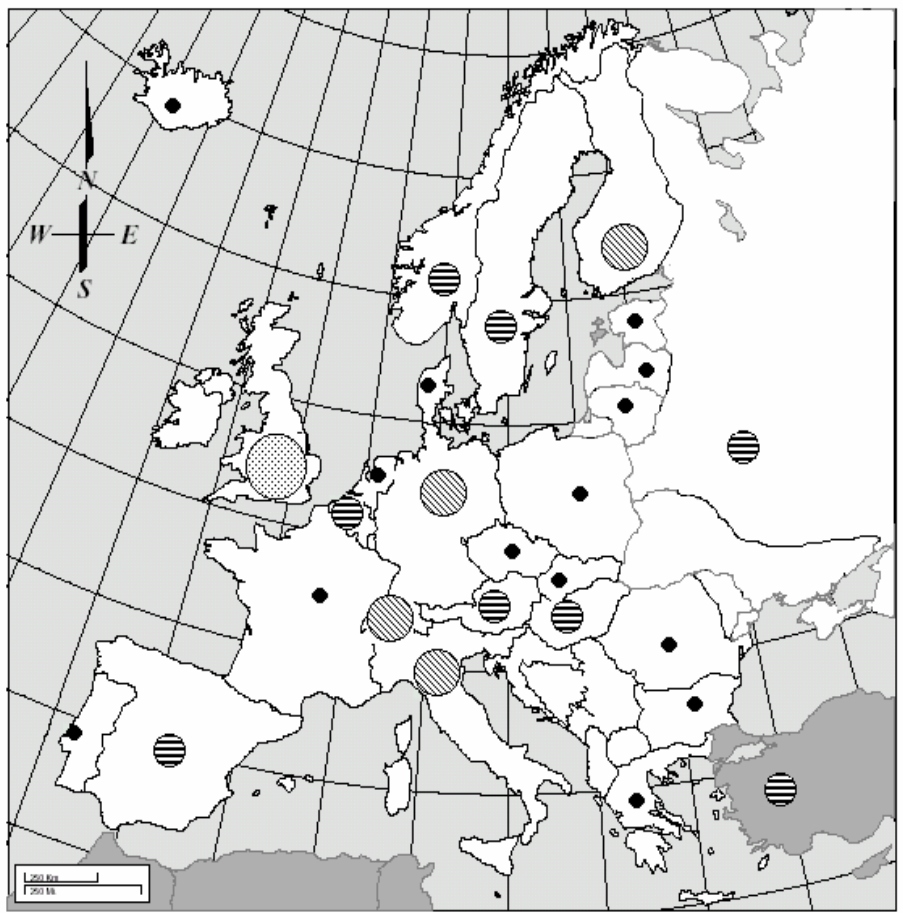

Ryc. 2. Struktura przestrzenna oddziałów w Europie w 2003 r.

Legenda: 1 oddział $\bigcirc 2-3 \ominus ; 4-5 \otimes ; 6-7 \odot$; pow. $7 \bigcirc$

Źródło: opracowanie własne na podstawie danych ze strony www.nokia.com 


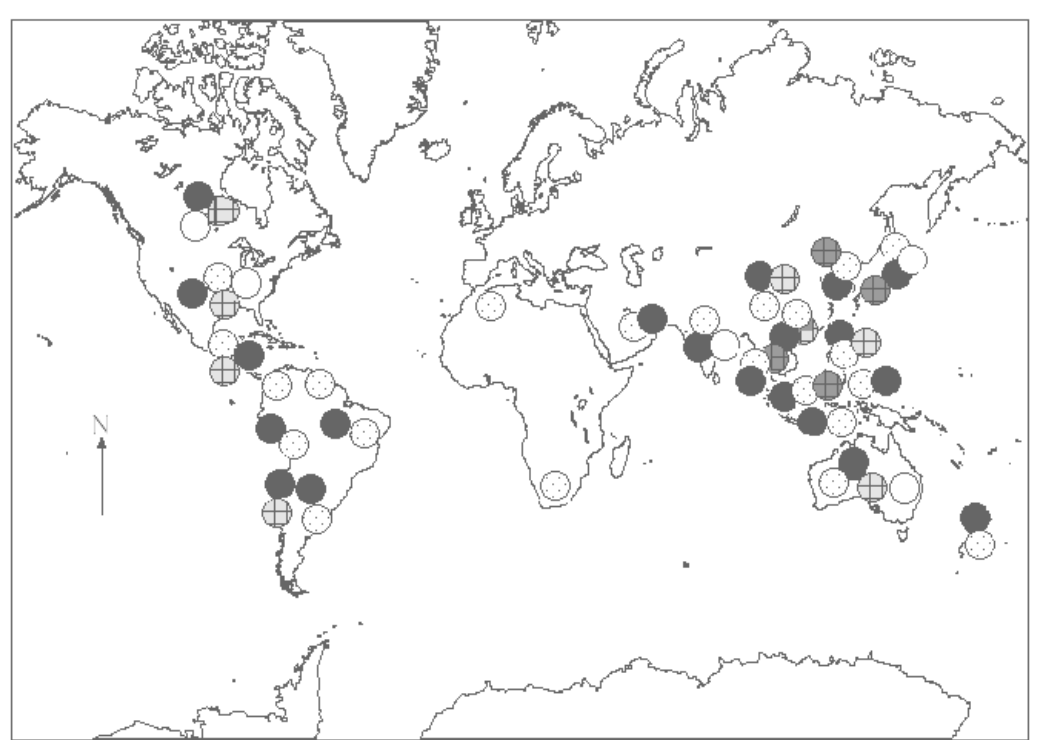

Ryc. 3. Struktura przestrzenna sektorów na świecie w 2003 r.

Legenda: Nokia Mobile Phones $\bigcirc$; Nokia Networks $\odot$; Nokia Ventures Organization $\oplus$; Research \&Develepment $\bigcirc$

Źródło: opracowanie własne na podstawie danych ze strony www.nokia.com

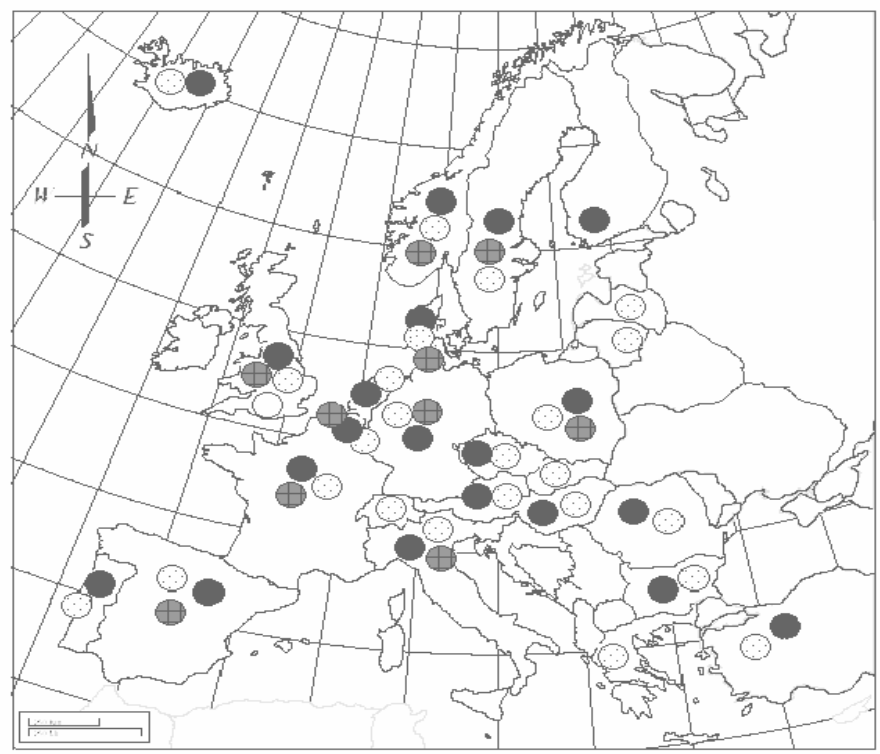

Ryc. 4. Struktura przestrzenna sektorów w Europie w 2003 r.

Legenda: Nokia Mobile Phones $\bigcirc$; Nokia Networks $\bigcirc$; Nokia Ventures Organization $\oplus$; Research \&Develepment $\bigcirc$

Źródło: opracowanie własne na podstawie danych ze strony www.nokia.com 
Innym obszarem koncentracji oddziałów jest teren Azji Południowo-Wschodniej zwłaszcza w Chinach (7) i Indiach (6). Analizując rozmieszczenie poszczególnych sektorów na świecie zauważyć można, iż Sektor Poszukiwania i Rozwój (Research and Development) zlokalizowany jest jedynie w 6 krajach, tzn. w Kanadzie, Stanach Zjednoczonych, Indiach, Japonii oraz Australii, natomiast w Europie sektor R\&D znajduje się jedynie w Wielkiej Brytanii.

Sektor Mobile Phones posiada swoje oddziały w Stanach Zjednoczonych, Kanadzie, Brazylii, Argentynie, Chile. Duża koncentracja oddziałów tego sektora znajduje się w Azji Południowo-Wschodniej, m.in. w Chinach, Indiach, Japonii i Korei Południowej. W Europie sektor ten posiada oddziały we wszystkich państwach, z wyjątkiem państw nadbałtyckich, Słowacji, Szwecji, Grecji. W tych wymienionych państwach ma swoje oddziały jedynie sektor Nokia Networks odpowiedzialny m.in. za wprowadzanie produktów związanych z Internetem. Oddziały sektora Nokia Venture Organization zlokalizowane są w Wielkiej Brytanii, Danii, Szwecji, Norwegii, Belgii, Francji, Hiszpanii, Portugalii, we Włoszech i Polsce.

\section{ZMIANA WARTOŚCI SPRZEDAŻY}

Od roku 1993 wartość sprzedaży w firmie Nokia systematycznie wzrastała. W roku 1993 osiagnęła wartość 4,6 mld USD. Najwyższy wzrost nastąpił w 1999 roku - 19.9 mld USD, w roku 2002 sprzedaż wzrosła 6-krotnie do wartości 30,2 mld USD (tab. 6, ryc. 5). Nokia jest firmą, która żywo reaguje na zmiany i wymogi otoczenia. Można to zauważyć w ciągle zmieniającej się strukturze firmy i powstawaniu nowych bądź zmianie i przystosowywaniu istniejących sektorów firmy.

W latach 1990-1994 w strukturze firmy wyróżniono 7 najważniejszych sektorów, m.in. Nokia Telecommunication, Nokia Mobile Phones, Nokia Consumer i Industrial Electronics oraz Nokia Data. W roku 1990 największą sprzedaż uzyskał sektor Nokia Consumer \& Industrial Electronics (tab. 7). Sektor ten zajmował się najprawdopodobniej m.in. przemysłem elektronicznym. Sprzedaż tego sektora kształtowała się na poziomie 1,2 mld USD, co stanowiło prawie 29\% ogólnej sprzedaży Nokia Group (tab. 8). Kolejnym ważnym sektorem okazał się Cables \& Machinery, którego sprzedaż w 1990 r. utrzymywała się na poziomie $1050 \mathrm{mln}$ USD, co stanowiło 24\%. Łącznie w 1990 r. te dwa sektory dokonały 53\% sprzedaży całej korporacji. W roku 1994 struktura sprzedaży uległa zmianie. Największy udział w sprzedaży przypadł na sektor Nokia Mobiles Phones, którego sprzedaż wyniosła 2098 mln USD, co stanowiło 35\% sprzedaży firmy. Innym sektorem, którego sprzedaż wzrosła, był Nokia Telecommunications. W 1994 r. sprzedaż jego była na poziomie 1354 mln USD co stanowiło, 22\% ogólnej sprzedaży. Ważne miejsce w tej strukturze miał nadal sektor Nokia Consumer \& Industrial Electronics, którego sprzedaż stanowiła 21,6\% ogólnej sprzedaży. Sprzedaż tych trzech sektorów łącznie kształtowała się na poziomie $77,6 \%$. 
Tabela 6. Zmiana wartości sprzedaży w latach 1993-2002

\begin{tabular}{|c|c|c|}
\hline Rok & $\begin{array}{c}\text { Wartość sprzedaży } \\
\text { w mln USD }\end{array}$ & $\begin{array}{c}\text { Dynamika sprzedaży } \\
1993=100 \%\end{array}$ \\
\hline 1993 & 4644,6 & 100,00 \\
\hline 1994 & 5914,7 & 127,35 \\
\hline 1995 & 7214,8 & 155,34 \\
\hline 1996 & 7706,9 & 165,93 \\
\hline 1997 & 10311,9 & 222,02 \\
\hline 1998 & 13432,6 & 289,21 \\
\hline 1999 & 19930,2 & 429,10 \\
\hline 2000 & 30619,0 & 659,24 \\
\hline 2001 & 31440,5 & 676,93 \\
\hline 2002 & 30256,1 & 651,43 \\
\hline
\end{tabular}

Źródło: własne obliczenia na podstawie danych ze strony www.nokia.com

sprzedaż

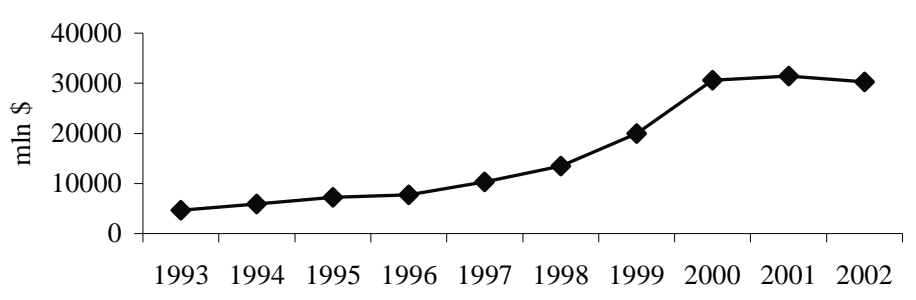

rok

Ryc. 5. Zmiana wartości sprzedaży w latach 1993-2002

Źródło: na podstawie tab. 6

Tabela 7. Sprzedaż wg sektorów w mln USD w latach 1990-1994

\begin{tabular}{|l|r|r|r|r|r|}
\hline \multicolumn{1}{|c|}{ Wyszczególnienie } & \multicolumn{1}{c|}{1990} & \multicolumn{1}{c|}{1991} & \multicolumn{1}{c|}{1992} & \multicolumn{1}{c|}{1993} & \multicolumn{1}{c|}{1994} \\
\hline Nokia Telecommunications & \multicolumn{1}{c|}{490,59} & 362,40 & 628,57 & 897,29 & 1353,58 \\
\hline Nokia Mobile Phones & 457,27 & 493,14 & 713,64 & 1237,54 & 2097,59 \\
\hline $\begin{array}{l}\text { Nokia Consumer } \\
\text { \& Industrial Electronics }\end{array}$ & 1254,20 & 1035,08 & 1129,16 & 1359,85 & 1326,72 \\
\hline Nokia Data & 959,03 & 0,00 & 0,00 & 0,00 & 0,00 \\
\hline Cables \& Machinery & 1050,36 & 924,92 & 905,32 & 966,87 & 934,53 \\
\hline Basic Industries & 356,92 & 298,90 & 0,00 & 0,00 & 0,00 \\
\hline Inne operacje & 0,00 & 0,00 & 265,38 & 294,00 & 311,44 \\
\hline Inter-business group & $-230,89$ & $-84,87$ & $-81,14$ & $-110,94$ & 109,17 \\
\hline Nokia Group & 4337,48 & 3029,57 & 3560,93 & 4644,61 & 6133,04 \\
\hline
\end{tabular}

Źródło: na podstawie danych ze strony www.nokia.com 
Tabela 8. Zmiana struktury sprzedaży w poszczególnych sektorach w latach 1990-1994

\begin{tabular}{|l|r|r|r|r|r|}
\hline \multicolumn{1}{|c|}{ Wyszczególnienie } & \multicolumn{1}{c|}{1990} & \multicolumn{1}{c|}{1991} & \multicolumn{1}{c|}{1992} & \multicolumn{1}{c|}{1993} & \multicolumn{1}{c|}{1994} \\
\hline Nokia Telecommunications & 11,31 & 11,96 & 17,65 & 19,32 & 22,07 \\
\hline Nokia Mobile Phones & 10,54 & 16,28 & 20,04 & 26,64 & 34,20 \\
\hline $\begin{array}{l}\text { Nokia Consumer } \\
\text { \& Industrial Electronics }\end{array}$ & 28,92 & 34,17 & 31,71 & 29,28 & 21,63 \\
\hline Nokia Data & 22,11 & 0,00 & 0,00 & 0,00 & 0,00 \\
\hline Cables \& Machinery & 24,22 & 30,53 & 25,42 & 20,82 & 15,24 \\
\hline Basic Industries & 8,23 & 9,87 & 0,00 & 0,00 & 0,00 \\
\hline Inne operacje & 0,00 & 0,00 & 7,45 & 6,33 & 5,08 \\
\hline Inter-business group & $-5,32$ & $-2,80$ & $-2,28$ & $-2,39$ & 1,78 \\
\hline Nokia Group & 100,00 & 100,00 & 100,00 & 100,00 & 100,00 \\
\hline
\end{tabular}

Źródło: na podstawie danych ze strony www.nokia.com

Tabela 9. Zmiana wartości sprzedaży w mln USD w poszczególnych sektorach w latach 1994-1997

\begin{tabular}{|l|r|c|c|c|}
\hline \multicolumn{1}{|c|}{ Wyszczególnienie } & \multicolumn{1}{c|}{1994} & 1995 & 1996 & 1997 \\
\hline Nokia Telecommunications & 0 & 2026,84 & 2613,27 & 3689,90 \\
\hline Nokia Mobile Phones & 0 & 3146,19 & 4229,48 & 5418,03 \\
\hline Inne operacje & 2571,324 & 2186,58 & 1018,61 & 1418,84 \\
\hline Inter busines & $-107,8$ & $-144,84$ & $-154,45$ & $-214,82$ \\
\hline Inne & 0 & 2041,73 & 864,16 & 1204,03 \\
\hline Nokia Group & 2463,524 & 7214,76 & 7706,92 & 10311,95 \\
\hline
\end{tabular}

Źródło: na podstawie danych ze strony www.nokia.com

Tabela 10. Zmiana sprzedaży w poszczególnych sektorach w latach 1998-2002

\begin{tabular}{|l|r|r|r|r|r|}
\hline \multicolumn{1}{|c|}{ Wyszczególnienie } & \multicolumn{1}{c|}{1998} & \multicolumn{1}{c|}{1999} & \multicolumn{1}{c|}{2000} & \multicolumn{1}{c|}{2001} & \multicolumn{1}{c|}{2002} \\
\hline Nokia Mobile Phones & 8134,56 & 13287,46 & 22062,10 & 23343,26 & 23396,69 \\
\hline Nokia Networks & 4425,12 & 5718,38 & 7775,71 & 7594,27 & 6591,31 \\
\hline Nokia Ventures Organization & 0 & 418,32 & 860,83 & 589,68 & 462,67 \\
\hline Inne & 872,93 & 506,02 & $-79,63$ & $-86,69$ & $-194,54$ \\
\hline Nokia Group & 13432,61 & 19930,18 & 30619,01 & 31440,53 & 30256,13 \\
\hline
\end{tabular}

Źródło: na podstawie danych ze strony www.nokia.com

W roku 1995 dokonano zmiany w strukturach firmy. Wyodrębniono dwa największe i najbardziej zyskowne sektory: Nokia Telecommunication i Nokia Mobile Phones. Od roku 1995 największy udział w sprzedaży stanowił sektor Nokia Mobile Phones (tab. 9). W 1997 r. sprzedaż w tym sektorze była na poziomie 5418 mln USD, a Nokia Telecommunication 3690 mln USD. W roku 1998 ponownie nastąpiła zmiana w strukturach firmy. Wyodrębniono sektory: Nokia Mobile Phones, Nokia Networks, Nokia Ventures Organizations. Największy udział w sprzedaży posiadał sektor Nokia Mobile Phones. W roku 2002 sprzedaż tego sektora kształtowała się na poziomie 23,3 mld USD (tab. 10), co stanowiło 77,3\% ogólnej sprzedaży całej korporacji. Natomiast w tym samym roku sprzedaż sektora Nokia Networks wyniosła 6,6 mld USD, tj. 22\% ogólnej sprzedaży. Sprzedaż tych dwóch sektorów razem stanowiła 99,3\% ogólnej sprzedaży Nokia Group. 
Analizując strukturę sprzedaży, należy zwrócić uwagę na główne rynki sprzedaży. W 2002 r. największym rynkiem sprzedaży dla artykułów firmy były Stany Zjednoczone. W tym państwie sprzedaż była na poziomie 4,7 mld USD, co stanowiło 15,5\% ogólniej sprzedaży firmy. Innym dominującym rynkiem była Wielka Brytania. W 2002 r. na jej obszarach sprzedaż wyniosła 3136 mln USD, czyli 10,4\% ogólnej sprzedaży (tab. 11). Należałoby tu podkreślić, że w porównaniu z wielkim rynkiem, jakim są Stany Zjednoczone pod względem terytorialnym, a szczególnie potencjałem ludnościowym, sprzedaż w Wielkiej Brytanii jest jedynie mniejsza o 5\%. Barierą i konkurencją dla firmy na terenie Stanów Zjednoczonych jest zapewne macierzysta Motorola.

Tabela 11. Dominujące rynki zbytu w latach 2000-2002

\begin{tabular}{|c|c|c|c|c|c|c|c|c|c|}
\hline \multirow{2}{*}{$\begin{array}{l}\text { Wyszcze- } \\
\text { gólnienie }\end{array}$} & \multicolumn{3}{|c|}{$\begin{array}{c}\text { Wartość sprzedaży } \\
\text { w mln USD }\end{array}$} & \multicolumn{3}{|c|}{ Struktura sprzedaży } & \multicolumn{3}{|c|}{ Dynamika sprzedaży } \\
\hline & 2000 & 2001 & 2002 & 2000 & 2001 & 2002 & 2000 & 2001 & 2002 \\
\hline $\begin{array}{l}\text { Ogółem } \\
\text { Nokia Group }\end{array}$ & 30619,01 & 31440,53 & 30256,13 & 100,00 & 100,00 & 100,00 & 100,00 & 105,69 & 87,82 \\
\hline \multicolumn{10}{|l|}{$\begin{array}{l}\text { Dominujące } \\
\text { rynki (10 kra- } \\
\text { jów) w tym: }\end{array}$} \\
\hline USA & 5354,50 & 5658,91 & 4702,32 & 17,49 & 18,00 & 15,54 & 100,00 & 99,29 & 110,01 \\
\hline UK & 2850,62 & 2830,46 & 3135,89 & 9,31 & 9,00 & 10,36 & 100,00 & 111,52 & 91,42 \\
\hline Chiny & 3089,52 & 3445,34 & 2824,42 & 10,09 & 10,96 & 9,34 & 100,00 & 77,67 & 71,69 \\
\hline Niemcy & 2599,63 & 2019,02 & 1863,79 & 8,49 & 6,42 & 6,16 & 100,00 & 93,97 & 107,96 \\
\hline Włochy & 1252,94 & 1177,34 & 1352,74 & 4,09 & 3,74 & 4,47 & 100,00 & 116,13 & 117,33 \\
\hline Francja & 1093,68 & 1270,08 & 1283,18 & 3,57 & 4,04 & 4,24 & 100,00 & 195,89 & 292,72 \\
\hline $\begin{array}{l}\text { Zjednoczone } \\
\text { Emiraty } \\
\text { Arabskie } \\
\end{array}$ & 318,53 & 623,95 & 932,40 & 1,04 & 1,98 & 3,08 & 100,00 & 204,04 & 185,84 \\
\hline Tajlandia & 448,56 & 915,26 & 833,62 & 1,46 & 2,91 & 2,76 & 100,00 & 84,47 & 73,20 \\
\hline Brazylia & 1064,45 & 899,14 & 779,18 & 3,48 & 2,86 & 2,58 & 100,00 & 123,43 & 121,76 \\
\hline Polska & 481,82 & 594,72 & 586,66 & 1,57 & 1,89 & 1,94 & 100,00 & 104,74 & 98,60 \\
\hline Razem & 18554,26 & 19434,24 & 18294,19 & 60,60 & 61,81 & 60,46 & 100,00 & 102,68 & 98,81 \\
\hline
\end{tabular}

Źródło: obliczenia własne na podstawie danych ze strony www.nokia.com

Tabela 12. Zmiana wartości wkładów kapitałowych firmy Nokia w latach 1990-2002

\begin{tabular}{|c|c|c|}
\hline Rok & $\begin{array}{c}\text { Wartość wkładów kapitało- } \\
\text { wych (aktywów)w mln USD }\end{array}$ & Dynamika $1990=100$ \\
\hline 1990 & 4252,0 & 100,0 \\
\hline 1991 & 3950,0 & 92,9 \\
\hline 1992 & 4162,6 & 97,9 \\
\hline 1993 & 4438,8 & 104,4 \\
\hline 1994 & 5458,4 & 128,4 \\
\hline 1995 & 6421,2 & 151,0 \\
\hline 1996 & 6521,9 & 153,4 \\
\hline 1997 & 8180,6 & 192,4 \\
\hline 1998 & 10114,3 & 237,9 \\
\hline 1999 & 14393,2 & 338,5 \\
\hline 2000 & 20049,1 & 471,5 \\
\hline 2001 & 22606,4 & 531,7 \\
\hline 2002 & 23513,6 & 553,0 \\
\hline
\end{tabular}

Źródło: własne obliczenia na podstawie danych ze strony www.nokia.com 


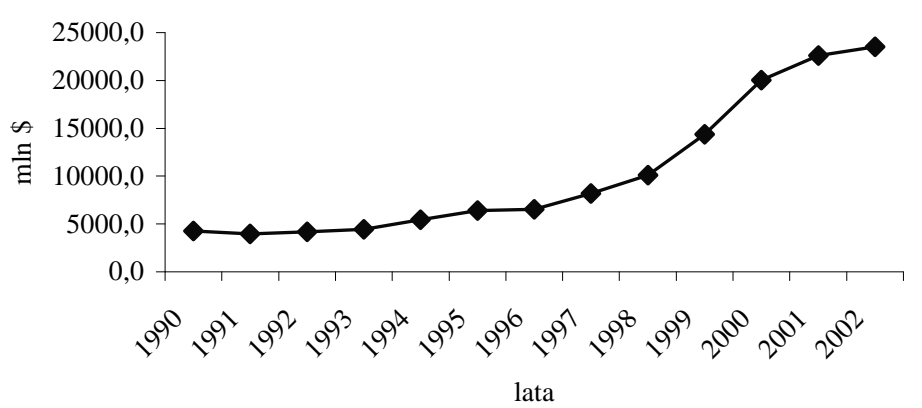

Ryc. 6. Zmiana wartości wkładów kapitałowych (aktywów) w latach 1990-2002 Źródło: własne obliczenia na podstawie danych ze strony www.nokia.com

Tabela 13. Zmiana dynamiki i wartości zysku w latach 1990-2002

\begin{tabular}{|c|c|c|}
\hline Rok & Zysk w mln USD & $\begin{array}{c}\text { Dynamika } \\
(1994=100 \%)\end{array}$ \\
\hline 1990 & 53,9 & 7 \\
\hline 1991 & $-41,4$ & -5 \\
\hline 1992 & $-141,7$ & -18 \\
\hline 1993 & $-225,4$ & -29 \\
\hline 1994 & 772,0 & 100 \\
\hline 1995 & 437,5 & 57 \\
\hline 1996 & 639,5 & 83 \\
\hline 1997 & 1226,8 & 159 \\
\hline 1998 & 1764,0 & 228 \\
\hline 1999 & 2597,6 & 336 \\
\hline 2000 & 3969,5 & 514 \\
\hline 2001 & 2217,6 & 287 \\
\hline 2002 & 3408,0 & 441 \\
\hline
\end{tabular}

Źródło: własne obliczenia na podstawie danych ze strony www.nokia.com

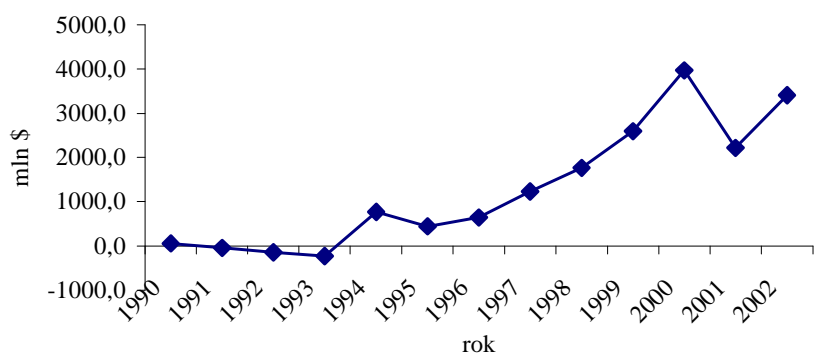

Ryc. 7. Zmiana wartości zysku w latach 1990-2002 Źródło: tab. 13

Główne rynki sprzedaży produktów firmy koncentrują się w Europie Zachodniej: w Wielkiej Brytanii, Niemczech, Francji i we Włoszech. Łącznie sprzedaż na tych obszarach 
stanowi 25,2\% ogólnej sprzedaży. W Europie ważnym i wyszczególnianym rynkiem sprzedaży okazał się obszar Polski, gdzie sprzedaż w 2002 r. wyniosła 586,66 mln USD, czyli 1,94\%. Dużym rynkiem jest obszar Chin, gdzie sprzedaż wyniosła 9,3\% (2,8 mld USD). W 2002 r. sprzedaż we wszystkich 10 wyróżnionych państwach wyniosła 18,3 mld USD, co stanowiło $60,5 \%$ ogólnej sprzedaży.

\section{WKŁAD KAPITAŁOWY}

W latach 1990-2002 obserwujemy wzrost wartości wkładów kapitałowych. W 1990 wartość wkładów kapitałowych firm utrzymywała się na poziomie 4,2 mld USD. Do roku 2002 wartość ta spadła do 4,2 mld USD (tab. 12), czyli zmniejszyła się o 2,1\%. Do roku 2002 można zauważyć systematyczny wzrost aktywów firmy. Dość duży wzrost, bo aż o 40\%, zanotowano w roku 1996 (wartość aktywów wyniosła 6,5 mld USD) oraz w 1997 r., kiedy to wartość aktywów wzrosła do 8,2 mld USD. W okresie 13-letnim wartość aktywów firmy wzrosła 5-krotnie z 4,2 mld USD w 1990 r. do 23,5 mld USD w 2002 r. (ryc. 6).

\section{ZMIANY ZYSKU}

Działalność każdej firmy nastawiona jest na przynoszenie zysku. Nokia Group w trzyletnim okresie 1991-1993 przynosiła straty. W roku 1991 firma straciła na działalności 41 mln USD, a w roku 1993 już 225 mln USD (tab. 13, ryc. 7). W roku 1993 największe straty zanotowano w sektorze Nokia Consumer i Industrial Electronics 146,4 mln USD (tab. 14). Od 1995 r. firma co roku odnotowywała już zyski z prowadzonej działalności. W roku 1995 zysk firmy wyniósł 437 mln USD, a w roku 1997 nastąpił wzrost do 1227 mln USD (tab. 15). Najwyższy zysk firma osiagnęła w 2000 r.: 3969,5 mln USD. W porównaniu z rokiem 1994 zysk był 5-krotnie wyższy. W roku 2002 osiagnęła zysk na poziomie $3408 \mathrm{mln}$ USD. W roku 2000 najwyższy zysk uzyskał sektor Nokia Mobile Phones (4918 mln USD) tab. 16, oraz w sektorze Nokia Networks 1369 mln USD. Po roku 2000 wszystkie sektory z wyjątkiem Nokia Mobile Phones przyniosły straty. Tendencja ta utrzymała się tak-że w 2002, zysk wypracowany przez Nokia Mobile Phones wyniósł wtedy 5243 mln USD.

Warto tu nadmienić, iż korporacja ta bardzo szybko reaguje na zmieniającą się sytua-cję. Analizując zyski wg sektorów widać wyraźnie, że w 1993 r. Sektor Nokia Consumer \& Industrial Electronics przyniósł straty (146,41 mln USD). Taki wynik był m.in. bodźcem do zmian w strukturze firmy, co doprowadziło do likwidacji tego sektora lub włączenia go do struktury innego sektora. Pozostały w strukturze organizacyjnej jedynie dwa najbardziej dochodowe sektory. Obecnie zaznacza się podobna sytuacja - sektory Nokia Ventures Organizations i Nokia Networks przynoszą firmie straty. Reagując żywo na tę sytuację, firma zapowiedziała wprowadzenie zmian w organizacji wewnętrznej. W roku 2004 nowa struktur- 
ra obejmować będzie cztery grupy biznesowe, ogólnofirmowe działy sprzedaży, marketingu, logistyki, produkcji i technologii oraz dział odpowiedzialny za opracowywanie strategii przedsiębiorstwa i działalność badawczo-rozwojową. Oddziały firmy zostaną zorganizowane w cztery grupy biznesowe, co pozwoli im najlepiej się dostosować do indywidualnej dynamiki poszczególnych branż. Powstanie Grupa Multimedia, której zadaniem będzie dostarczanie materiałów multimedialnych przeznaczonych do urządzeń bezprzewodowych, np. zdjęć, gier, utworów muzycznych i wielu innych atrakcji. Nowo powstała Grupa Enterprise Solutions będzie oferować szeroką gamę terminali i kompatybilnych z nimi rozwiązań do łączności mobilnej, opartych na kompleksowej architekturze sieci bezprzewodowej.

Tabela 14. Zmiana wartości zysków w mln USD w poszczególnych sektorach w latach 1990-1994

\begin{tabular}{|l|r|r|r|r|r|}
\hline \multicolumn{1}{|c|}{ Wyszczególnienie } & 1990 & 1991 & \multicolumn{1}{c|}{1992} & \multicolumn{1}{c|}{1993} & 1994 \\
\hline Nokia Telecommunications & 0 & 0 & 83,69 & 192,67 & 333,20 \\
\hline Nokia Mobile Phones & 0 & 0 & 85,65 & 186,2 & 342,02 \\
\hline $\begin{array}{l}\text { Nokia Consumer } \\
\text { \& Industrial Electronics }\end{array}$ & 0 & 0 & $-153,47$ & $-146,41$ & 3,72 \\
\hline Cables \& Machinery & 75,07 & 19,01 & 22,34 & 51,16 & 37,44 \\
\hline Basic Industries & 48,22 & 42,34 & 0 & 0 & 0,00 \\
\hline Inne operacje & $-13,33$ & $-35,08$ & 18,23 & 3,53 & $-11,56$ \\
\hline Nokia Group & 109,96 & 26,26 & 56,45 & 287,1 & 704,82 \\
\hline
\end{tabular}

Źródło: na podstawie danych ze strony www.nokia.com

Tabela 15. Zmiana wartości zysków w mln USD w poszczególnych sektorach w latach 1994-1997

\begin{tabular}{|l|c|c|c|c|}
\hline \multicolumn{1}{|c|}{ Wyszczególnienie } & 1994 & 1995 & 1996 & 1997 \\
\hline Nokia Telecommunications & 333,2 & 533,512 & 584,472 & 794,388 \\
\hline Nokia Mobile Phones & 342,02 & 343,588 & 280,476 & 752,052 \\
\hline Inne & 29,596 & 105,252 & $-28,812$ & 110,544 \\
\hline Nokia Group & 704,816 & 982,352 & 836,136 & 1656,984 \\
\hline
\end{tabular}

Źródło: na podstawie danych ze strony www.nokia.com

Tabela 16. Zmiana wartości zysków w mln USD w poszczególnych sektorach w latach 1998-2002

\begin{tabular}{|l|c|c|c|c|c|}
\hline \multicolumn{1}{|c|}{ Wyszczególnienie } & \multicolumn{1}{c|}{1998} & 1999 & \multicolumn{1}{c|}{2000} & \multicolumn{1}{c|}{2001} & \multicolumn{1}{c|}{2002} \\
\hline Nokia Mobile Phones & 1552,32 & 3123,79 & 4918,03 & 4557,17 & 5242,61 \\
\hline Nokia Networks & 967,68 & 1090,66 & 1368,86 & $-73,58$ & $-49,39$ \\
\hline $\begin{array}{l}\text { Nokia Ventures } \\
\text { Organization }\end{array}$ & 0 & $-176,4$ & $-390,10$ & $-861,84$ & $-142,13$ \\
\hline Inne & $-11,088$ & $-98,78$ & $-74,59$ & $-232,85$ & $-232,85$ \\
\hline Nokia Group & 2508,912 & 3939,26 & 5822,21 & 3388,90 & 4818,24 \\
\hline
\end{tabular}

Źródło: na podstawie danych ze strony www.nokia.com 


\section{ZATRUDNIENIE}

Nokia Corporations zatrudnia obecnie prawie 52 tys. osób. Od roku 1990 zatrudnienie zmniejszało się z 37 tys. w 1990 r. do 25,8 tys. w 1993 (tab. 17). Od roku 1993 zatrudnienie w firmie zaczyna wzrastać: w roku 1994 wynosiło 28 tys., czyli w okresie 9-letnim wzrosło prawie dwukrotnie. Od roku 1994 zatrudnienie systematycznie wzrastało aż do roku 2000, kiedy to osiagnięto wartość 60 tys. zatrudnionych (ryc. 8). Od 2000 r. zatrudnienie zaczyna stopniowo spadać, tj. z 60,3 tys. w 2000 r. do 52 tys. w roku 2002. Porównując roku 1990 i 2002 zauważamy, iż zatrudnienie w firmie w 12-letnim badanym okresie wzrosło o $40 \%$, tj. z 37,3 tys. osób w 1990 do 51,7 tys. osób w 2002.

Analizując strukturę zatrudnienia, zauważyć można, że w roku 1990 większy odsetek zatrudnionych stanowiła ludność spoza terenów Finlandii. W roku 1990 w Finlandii zatrudnionych było 18,09 tys. osób, co stanowiło 48,5\% (tab. 18). W tym samym roku w swoich filiach poza terenem kraju Nokia zatrudniała 19,2 tys. Od roku 1990 do roku 1996 wzrastało systematycznie zatrudnienie na terenie kraju. W 1992 Nokia ogółem zatrudniała 26,7 tys. osób, z czego 13,7 tys. osób, tj. 51,4\% zatrudnionych było na terenie Finlandii. Do roku 1996 systematycznie wzrastało zatrudnienie na terenie Finlandii, natomiast od roku 1997 systematycznie zaczyna maleć zatrudnienie na terenie kraju macierzystego, a wzrasta zatrudnienie $w$ innych krajach, szczególnie europejskich (ryc. 9, ryc. 10). W roku 2002 na terenie Finlandii Nokia zatrudniała 22,6 tys. osób, co stanowiło 42,9\% ogólnego zatrudnienia, natomiast w filiach zatrudnionych było 30,1 tys. osób, czyli 57,1\%. Obok Finlandii drugim ważnym obszarem są Stany Zjednoczone, gdzie zatrudnienie kształtuje się na poziomie 6,6 tys. osób, co stanowi 13\% ogólnego zatrudnienia w firmie (tab. 19). Ważnym rynkiem są także Chiny, gdzie zatrudnionych jest 4,8 tys.

osób

$(9,2 \%)$

oraz

Niemcy

3,6 tys. czyli $7 \%$. Ogółem na terenie Europy zatrudnienie w firmie znalazło 31,4 tys. osób, co stanowi $60,8 \%$ zatrudnienia.

Tabela 17. Zmiana wielkości zatrudnienia i dynamika zatrudnienia w latach 1990-2002

\begin{tabular}{|l|c|c|}
\hline \multicolumn{1}{|c|}{ Rok } & Zatrudnienie & Dynamika \% \\
\hline 1990 & 37336 & 100 \\
\hline 1991 & 29167 & 78 \\
\hline 1992 & 26770 & 72 \\
\hline 1993 & 25801 & 69 \\
\hline 1994 & 28043 & 75 \\
\hline 1995 & 31948 & 86 \\
\hline 1996 & 31768 & 85 \\
\hline 1997 & 35490 & 95 \\
\hline 1998 & 41091 & 110 \\
\hline 1999 & 51177 & 137 \\
\hline 2000 & 60289 & 161 \\
\hline 2001 & 53849 & 144 \\
\hline 2002 & 51748 & 139 \\
\hline
\end{tabular}

Źródło: obliczenia własne na podstawie danych ze strony www.nokia.com 


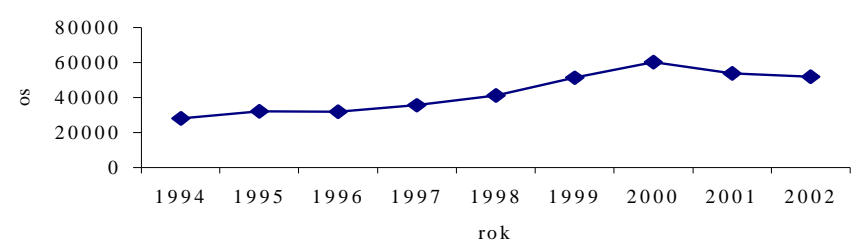

Ryc. 8. Zmiana wielkości zatrudnienia w latach 1990-2002 Źródło: tab. 17

Tabela 18. Zmiana zatrudnienia w firmie Nokia i struktura zatrudnienia w Finlandii i zagranicą w latach 1990-1997

\begin{tabular}{|l|c|c|c|c|c|c|}
\hline \multirow{2}{*}{ Rok } & \multicolumn{3}{|c|}{ Zatrudnienie } & \multicolumn{3}{c|}{ Struktura zatrudnienie } \\
\cline { 2 - 7 } & Ogółem & Finlandia & Zagraniczne & Ogółem \% & Finlandia & Zagraniczne \\
\hline 1990 & 37336 & 18096 & 19240 & 100 & 48,5 & 51,5 \\
\hline 1991 & 29167 & 14588 & 14579 & 100 & 50,0 & 50,0 \\
\hline 1992 & 26770 & 13752 & 13018 & 100 & 51,4 & 48,6 \\
\hline 1993 & 25801 & 13813 & 11988 & 100 & 53,5 & 46,5 \\
\hline 1994 & 28043 & 14984 & 13059 & 100 & 53,4 & 46,6 \\
\hline 1995 & 31948 & 17821 & 14127 & 100 & 55,8 & 44,2 \\
\hline 1996 & 31766 & 17999 & 13767 & 100 & 56,7 & 43,3 \\
\hline 1997 & 35490 & 19342 & 16148 & 100 & 54,5 & 45,5 \\
\hline 1998 & 41091 & 20978 & 20113 & 100 & 51,1 & 48,9 \\
\hline 1999 & 51177 & 23155 & 28022 & 100 & 45,2 & 54,8 \\
\hline 2000 & 58708 & 24495 & 34213 & 100 & 41,7 & 58,3 \\
\hline 2001 & 57716 & 23653 & 34063 & 100 & 41,0 & 59,0 \\
\hline 2002 & 52714 & 22615 & 30099 & 100 & 42,9 & 57,1 \\
\hline
\end{tabular}

Źródło: własne obliczenia na podstawie danych ze strony www.nokia.com

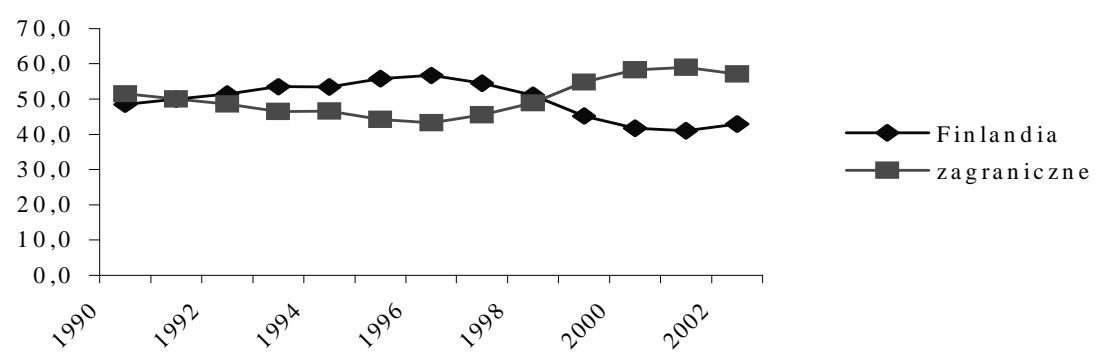

Ryc. 9. Zmiana wartości zatrudnienia w Finlandii i zagranicą w latach 1990-2002 Źródło: własne obliczenia na podstawie danych ze strony www.nokia.com 


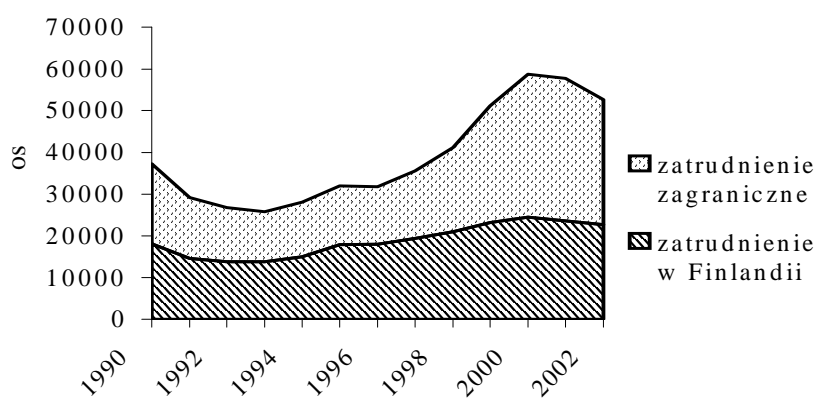

Ryc. 10. Zmiana wielkości zatrudnienia w Finlandii i zagranicą w korporacji Nokia w latach 1990-2003

Źródło: opracowanie własne na podstawie danych ze strony www.nokia.com

Tabela 19. Zmiana i struktura zatrudnienia w wybranych państwach w latach 2000-2002

\begin{tabular}{|l|c|r|r|r|r|r|}
\hline \multirow{2}{*}{$\begin{array}{l}\text { Wyszcza- } \\
\text { gólnienie }\end{array}$} & \multicolumn{2}{|c|}{2000} & \multicolumn{2}{c|}{2001} & \multicolumn{2}{c|}{2002} \\
\cline { 2 - 7 } & Zatrudnienie & Struktura & Zatrudnienie & Struktura & Zatrudnienie & Struktura \\
\hline Finlandia & 24379 & 40,44 & 22246 & 41,31 & 22535 & 43,55 \\
\hline USA & 8765 & 14,54 & 7298 & 13,55 & 6661 & 12,87 \\
\hline Chiny & 5675 & 9,41 & 5202 & 9,66 & 4778 & 9,23 \\
\hline Niemcy & 4747 & 7,87 & 3892 & 7,23 & 3620 & 7,00 \\
\hline $\begin{array}{l}\text { Wielka } \\
\text { Brytania }\end{array}$ & 2777 & 4,61 & 2286 & 4,25 & 2139 & 4,13 \\
\hline Wegry & 1972 & 3,27 & 1937 & 3,60 & 1975 & 3,82 \\
\hline Brazylia & 1260 & 2,09 & 1413 & 2,62 & 1466 & 2,83 \\
\hline Dania & 1266 & 2,10 & 1166 & 2,17 & 1176 & 2,27 \\
\hline Meksyk & 1222 & 2,03 & 1198 & 2,22 & 1158 & 2,24 \\
\hline $\begin{array}{l}\text { Korea } \\
\text { Południowa }\end{array}$ & 937 & 1,55 & 864 & 1,60 & 821 & 1,59 \\
\hline Razem & 53000 & 87,91 & 47502 & 88,21 & 46329 & 89,53 \\
\hline Nokia ogółem & 60289 & 100,00 & 53849 & 100,00 & 51748 & 100,00 \\
\hline
\end{tabular}

Źródło: obliczenia własne na podstawie danych ze strony www.nokia.com

Tabela 20. Zmiana wielkości zatrudnienia w poszczególnych sektorach w latach 1990-1994

\begin{tabular}{|l|r|r|r|r|r|}
\hline \multicolumn{1}{|c|}{ Wyszczególnienie } & 1990 & 1991 & 1992 & 1993 & 1994 \\
\hline Nokia Telecommunications & 3821 & 4474 & 4905 & 5867 & 7187 \\
\hline Nokia Mobile Phones & 3271 & 3545 & 3147 & 3759 & 5826 \\
\hline $\begin{array}{l}\text { Nokia Consumer } \\
\text { \& Industrial Electronics }\end{array}$ & 11573 & 10854 & 10261 & 8675 & 8307 \\
\hline Nokia Data & 7719 & $*$ & $*$ & $*$ & $*$ \\
\hline Cables \& Machinery & 8373 & 7766 & 6682 & 5893 & 4963 \\
\hline Basic Industries & 2112 & 1874 & $*$ & $*$ & $*$ \\
\hline Inne operacje & 467 & 654 & 1775 & 1607 & 1760 \\
\hline Nokia Group & 37336 & 29167 & 26770 & 25801 & 28043 \\
\hline
\end{tabular}

* brak danych

Źródło: na podstawie danych ze strony www.nokia.com 
Tabela 21. Zmiana struktury zatrudnienia w poszczególnych sektorach w latach 1990-1994

\begin{tabular}{|l|r|r|r|r|r|}
\hline \multicolumn{1}{|c|}{ Wyszczególnienie } & \multicolumn{1}{c|}{1990} & \multicolumn{1}{c|}{1991} & \multicolumn{1}{c|}{1992} & \multicolumn{1}{c|}{1993} & \multicolumn{1}{c|}{1994} \\
\hline Nokia Telecommunications & 10,23 & 15,34 & 18,32 & 22,74 & 25,63 \\
\hline Nokia Mobile Phones & 8,76 & 12,15 & 11,76 & 14,57 & 20,78 \\
\hline $\begin{array}{l}\text { Nokia Consumer } \\
\text { \& Industrial Electronics }\end{array}$ & 31,00 & 37,21 & 38,33 & 33,62 & 29,62 \\
\hline Nokia Data & 20,67 & 0,00 & 0,00 & 0,00 & 0,00 \\
\hline Cables \& Machinery & 22,43 & 26,63 & 24,96 & 22,84 & 17,70 \\
\hline Basic Industries & 5,66 & 6,43 & 0,00 & 0,00 & 0,00 \\
\hline Inne operacje & 1,25 & 2,24 & 6,63 & 6,23 & 6,28 \\
\hline Nokia Group & 100,00 & 100,00 & 100,00 & 100,00 & 100,00 \\
\hline
\end{tabular}

Źródło: Obliczenia własne na podstawie danych ze strony www.nokia.com

Tabela 22. Zmiana wielkości zatrudnienia w poszczególnych sektorach w latach 1994-1997

\begin{tabular}{|l|r|r|r|r|}
\hline \multicolumn{1}{|c|}{ Wyszczególnienie } & 1994 & 1995 & 1996 & 1997 \\
\hline Nokia Telecommunications & 7187 & 9915 & 12558 & 15710 \\
\hline Nokia Mobile Phones & 5826 & 10616 & 10927 & 12637 \\
\hline Inne & 15030 & 11417 & 8281 & 7149 \\
\hline Nokia Group & 28043 & 31948 & 31766 & 35496 \\
\hline
\end{tabular}

Źródło: na podstawie danych ze strony www.nokia.com

Biorąc pod uwagę zatrudnienie w poszczególnych sektorach, można zauważyć, że w 1990 r. najwięcej osób zatrudnionych było w sektorze Nokia Consumer \& Industrial Electronics (11,6 tys. osób, co stanowiło 31\% zatrudnienia- tab. 20 i tab. 21). W roku 1994 po wprowadzeniu zmian organizacyjnych w sektorze Nokia Telecommunications zatrudnienie kształtowało się na poziomie 7,2 tys. osób, czyli 26\% (tab. 22, 23). W roku 2002 proporcje uległy zmianie, najwięcej zatrudniał sektor Nokia Mobiles Phones: 26,1 tys. osób, czyli 50\% oraz w Nokia Networks 18,5 tys. osób, tj. 35\% (tab. 24, 25).

\section{NAKŁADY NA BADANIA}

W latach 1998-2002 można zauważyć systematyczny wzrost nakładów na rozwój i badania. W roku 1998 Nokia przeznaczyła na ten cel 1159 mln USD, a w 2002 już 3076 mln USD, czyli prawie 3-krotnie więcej (tab. 26). Najwięcej na badania w 2002 r. przeznaczył sektor Nokia Mobile Phones, bo aż 1899 mln USD, czyli 62\% (tab. 27). Przemysł telefonów komórkowych rozwija się bardzo dynamicznie, aby utrzymać się na konkurencyjnej pozycji, firma musi przeznaczać duże nakłady pieniężne na rozwój. 
Tabela 23. Struktura wielkości zatrudnienia w poszczególnych sektorach w latach 1994-1997

\begin{tabular}{|l|r|r|r|r|}
\hline \multicolumn{1}{|c|}{ Wyszczególnienie } & \multicolumn{1}{c|}{1994} & \multicolumn{1}{c|}{1995} & \multicolumn{1}{c|}{1996} & \multicolumn{1}{c|}{1997} \\
\hline Nokia Telecommunications & 25,63 & 31,03 & 39,53 & 44,26 \\
\hline Nokia Mobile Phones & 20,78 & 33,23 & 34,40 & 35,60 \\
\hline Inne & 53,60 & 35,74 & 26,07 & 20,14 \\
\hline Nokia Group & 100,00 & 100,00 & 100,00 & 100,00 \\
\hline
\end{tabular}

Źródło: obliczenia własne na podstawie danych ze strony www.nokia.com

Tabela 24. Zmiana wielkości zatrudnienia w poszczególnych sektorach w latach 1998-2002

\begin{tabular}{|l|r|r|r|r|r|}
\hline \multicolumn{1}{|c|}{ Wyszczególnienie } & \multicolumn{1}{c|}{1998} & \multicolumn{1}{c|}{1999} & \multicolumn{1}{c|}{2000} & \multicolumn{1}{c|}{2001} & \multicolumn{1}{c|}{2002} \\
\hline Nokia Mobile Phones & 16064 & 20975 & 27353 & 27320 & 26090 \\
\hline Nokia Networks & 19280 & 22804 & 23508 & 22040 & 18463 \\
\hline Nokia Ventures Organization & & 1256 & 2222 & 2155 & 1566 \\
\hline Inne & 5747 & 6142 & 5625 & 6201 & 6595 \\
\hline Nokia Group & 41091 & 51177 & 58708 & 57716 & 52714 \\
\hline
\end{tabular}

Źródło: na podstawie danych ze strony www.nokia.com

Tabela 25. Zmiana struktury zatrudnienia w poszczególnych sektorach w latach 1998-2002

\begin{tabular}{|l|r|r|r|r|r|}
\hline \multicolumn{1}{|c|}{ Wyszczególnienie } & \multicolumn{1}{c|}{1998} & \multicolumn{1}{c|}{1999} & \multicolumn{1}{c|}{2000} & \multicolumn{1}{c|}{2001} & \multicolumn{1}{c|}{2002} \\
\hline Nokia Mobile Phones & 39,09 & 40,99 & 46,59 & 47,34 & 49,49 \\
\hline Nokia Networks & 46,92 & 44,56 & 40,04 & 38,19 & 35,02 \\
\hline Nokia Ventures Organization & 0,00 & 2,45 & 3,78 & 3,73 & 2,97 \\
\hline Inne & 13,99 & 12,00 & 9,58 & 10,74 & 12,51 \\
\hline Nokia Group & 100,00 & 100,00 & 100,00 & 100,00 & 100,00 \\
\hline
\end{tabular}

Źródło: Obliczenia własne na podstawie danych ze strony www.nokia.com

Tabela 26. Zmiana wartości nakładów na rozwój i badania w poszczególnych sektorach w latach 1998-2002

\begin{tabular}{|l|r|r|r|r|r|}
\hline \multicolumn{1}{|c|}{ Wyszczególnienie } & \multicolumn{1}{c|}{1998} & \multicolumn{1}{c|}{1999} & \multicolumn{1}{c|}{2000} & \multicolumn{1}{c|}{2001} & \multicolumn{1}{c|}{2002} \\
\hline Nokia Mobile Phones & 526,176 & 841,68 & 1316,45 & 1611,79 & 1899,07 \\
\hline Nokia Networks & 568,51 & 783,216 & 1021,10 & 1144,08 & 1002,96 \\
\hline Nokia Ventures Organization & 0 & 110,88 & 236,88 & 222,77 & 137,09 \\
\hline Inne & 64,512 & 33,26 & 30,24 & 30,24 & 37,30 \\
\hline Nokia Group & 1159,2 & 1769,04 & 2604,67 & 3008,88 & 3076,42 \\
\hline
\end{tabular}

Źródło: na podstawie danych ze strony www.nokia.com

Tabela 27. Zmiana struktury nakładów na rozwój i badania w poszczególnych sektorach w latach 1998-2002

\begin{tabular}{|l|r|r|r|r|r|}
\hline \multicolumn{1}{|c|}{ Wyszczególnienie } & \multicolumn{1}{c|}{1998} & \multicolumn{1}{c|}{1999} & \multicolumn{1}{c|}{2000} & \multicolumn{1}{c|}{2001} & \multicolumn{1}{c|}{2002} \\
\hline Nokia Mobile Phones & 45,39 & 47,58 & 50,54 & 53,57 & 61,73 \\
\hline Nokia Networks & 49,04 & 44,27 & 39,20 & 38,02 & 32,60 \\
\hline Nokia Ventures Organization & 0,00 & 6,27 & 9,09 & 7,40 & 4,46 \\
\hline Inne & 5,57 & 1,88 & 1,16 & 1,01 & 1,21 \\
\hline Nokia Group & 100,00 & 100,00 & 100,00 & 100,00 & 100,00 \\
\hline
\end{tabular}

Źródło: obliczenia własne na podstawie danych ze strony www.nokia.com 


\section{PODSUMOWANIE}

Przedstawiona analiza wskazuje, iż Nokia jest bardzo dynamicznie rozwijająca się korporacją. Swoją pozycję zawdzięcza dbałości o systematyczny rozwój nowoczesnych technologii i produktów: od przetwórstwa drewna, poprzez zakłady produkujące gumę i kable, aż po produkcję wysokiej technologii i najnowszej generacji telefonów komórkowych. Szybkie reagowanie na uwarunkowania i wymogi rynku przyczyniły się do wzrostu wartości rynkowej firmy i tym samym wzrostu pozycji w rankingu ogólnoświatowym z miejsca 224 w 1996 r. do 24 w 2003 r.

\section{Literatura}

Berezowski S., 1980, Metody badań w geografii ekonomicznej, WSiP, Warszawa

„Bussines Week”, 1990, 1996, 1997, 1998, 1999, 2000, 2001

„Bussiness Week Polska”, 2000, 2001, 2002, 2003

Durka B., 2000, Działalność korporacji międzynarodowych na świecie i w Polsce. Inwestycje zagraniczne w Polsce, Raport Jubileuszowy. Instytut Koniunktur i Cen Handlu Zagranicznego, Warszawa

Dytwald J.A., 1997, Wspótczesne koncepcje zarzqdzania korporacjami, Wyd. Wyższej Szkoły Przedsiębiorczości i Zarządzania, Warszawa

Gwiazda A., 1998, Globalizacja i regionalizacja gospodarki światowej, Wyd. A. Marszałek, Toruń

Oficjalne strony internetowe: www.nokia.com, www.nokia.pl. www.bussinesweek.com

Wajda E., 2002, Proces kształtowania się ponadnarodowych firm na przyktadzie Motoroli, Praca magisterska wykonana w Zakładzie Przedsiębiorczości i Gospodarki Przestrzennej, Instytut Geografii Akademii Pedagogicznej w Krakowie pod kierunkiem prof. Z. Zioło

Zioło Z., 2001, Wspótczesne tendencje rozwoju przemystu i ich problematyka badawcza, Prace Komisji Geografii Przemysłu PTG, nr 2, Problematyka przemian struktur przestrzennych przemystu, pod red. Z. Zioło, Kraków

Zioło Z., 2001, Struktura branżowa i koncentracja przestrzenna wiodacych światowych firm przemystowych, Prace Komisji Geografii Przemysłu PTG, nr 3, Problemy przemian struktur przemystowych w procesie wdrażania regut gospodarki rynkowej, pod red. Z. Zioło, Kraków

Zorska A., 2000, Korporacje transnarodowe, [w:] Biznes międzynarodowy - obszary decyzji strategicznych, pod red. M.K. Nowakowskiego, Wyd. Key Text, Warszawa

Zorska A., 2000, Ku globalizacji? Przemiany w korporacjach transnarodowych i gospodarce światowej, PWN, Warszawa 